\title{
A Review of Structural Relationship Between Supply Chain Management and Organizational Performance in Malaysian Automotive Industry
}

\author{
Mira Asmida Mohd Sah", Nurul Fadly Habidin, Nor Azrin Md Latip, Mad Ithnin Salleh \\ Department of Management and Leadership, Faculty of Management and Economics, Universiti Pendidikan Sultan Idris, \\ 35900 Tanjung Malim, Perak, Malaysia \\ *Corresponding Author: asmida7613@yahoo.com
}

Copyright (C) 2014 Horizon Research Publishing All rights reserved.

\begin{abstract}
Nowadays, in international business dynamic, supply chain management has become a critical strategic initiative in a global competitive environment. In consequence of increased competition in both domestic and international market, firm can no longer effectively compete in isolation of the suppliers and other entities in the supply chain. Supply Chain Management (SCM) practices have mostly been analyzed in manufacturing business. The SCM has been recognized as a strategy that could lead companies to gain competitive advantage, other than to achieve greater business performance. The SCM seeks to enhance competitive performance by closely integrating internal functions within a company and effectively linking them with external operations of suppliers, customers, and other channel members. There are several elements that can be selected to support SCM practices and organizational performance in the automotive industries. The purpose of this study is to propose a structural relationship of supply chain management practices and organizational performance model for Malaysian automotive industries. Since this study is a concept paper, most of the previous study taken as a basic guided for this research. Therefore, the conceptual model using Structural Equation Model (SEM) has been proposed and research hypothesis are also being developed. The paper culminates with suggested future research.
\end{abstract}

Keywords Supply Chain management, Continuous Improvement, Organizational Performance, Performance Measurement

\section{Introduction}

Organizations today operate in an uncertain and competitive business environment. One way to address these challenges is to implement supply chain management (SCM). The term SCM has been used to explain the logistics activities not only internally within a company but also externally between companies other than planning and control of materials and information flows [1,2].

Besides, the purpose of SCM are to improve individual organization performance and to improve the seamlessly across the supply chain as an effective weapon is the goal of SCM [3]. SCM practices implemented to achieve superior supply chain performance require internal cross-functional integration within a firm and external integration with suppliers or customers to be successful [4,5] entire supply chain while to create sourcing, making and delivery processes and logistics functions.

This study focuses on manufacturing firms in Malaysia since Malaysia's main GDP contribution still comes from manufacturing. Therefore, in order to ensure Malaysian firms remain competitive, they need to manage effectively their supply chain. In automotive industry, [6] reported that the global trend in automotive supply chain, and how the development of Asian automotive industry is relying on the capabilities of local supply chain.

The purpose of this research is to propose structural relationship of supply chain management practices and organizational performance. SCM practices are defines as the set of organization's activities undertake to promote an effective management of its supply chain [3].

The remainder of this paper is organized as follows. The next section presents the research framework that provides the definitions and theory underlying each dimension of SCM practices and the relationship between supply chain management practices and organizational performance. The research hypotheses, methodology, and a proposed research model are to be found in the sections that follow. The last section presents the conclusion and direction for future work.

\section{Literature Review}

Figure 1 present the SCM practices framework developed in this research. The framework proposes that SCM practices will have an impact on OP directly. SCM practices are 
conceptualized as a five-dimensional construct as well as four performance outcomes (OP). Five dimension for SCMP are Leadership (L), Supplier Relationship (SR), Customer Focus (CF), Quality Information and Analysis (QIA) and Internal Lean Practices (ILP) while four dimension for OP are: Financial (F), Customer (C), Internal business process (IBP) and, Innovation and learning growth (ILG).

\subsection{Supply Chain Management Practice}

Various definitions of SCM had stated among the previous researchers with reflect different perspective. According to [7] defined SCM as the management philosophy aimed at integrating a network of upstream linkages (sources of supply), internal linkages inside the organization and downstream linkages (distribution and ultimate customer) in performing specific processes and activities that will ultimately create and optimize value for the customer in the form of products and services which are specifically aimed at satisfying customer demands. Table 1 shown below the summary of SCM definition.

Table 1. Definition of Supply Chain

\begin{tabular}{|c|c|}
\hline Supply chain management & Source \\
\hline $\begin{array}{c}\text { SCM is a wider concept of logistics and the management of } \\
\text { upstream and downstream relationships with suppliers and } \\
\text { customers to deliver superior customer value at less cost to } \\
\text { the supply chain as a whole. }\end{array}$ & {$[8]$} \\
\hline $\begin{array}{c}\text { SCM is the management and control of all materials, funds } \\
\text { and related information in the logistics process from the } \\
\text { acquisition of raw materials to the delivery of finished } \\
\text { products to the end user. }\end{array}$ & {$[9]$} \\
\hline $\begin{array}{c}\text { SCM is the systems approach to managing the entire flow of } \\
\text { information, materials and services from the raw materials } \\
\text { suppliers through factories and warehouses to the end } \\
\text { customer. }\end{array}$ & {$[10]$} \\
\hline
\end{tabular}

SCM practices are defines as the set of organization's activities undertake to promote an effective management of its supply chain. Besides, according to [3], the elements of supply chain practices include strategic supplier partnership, customer relationship, information sharing, information quality, internal lean practices, and postponement. Table 2 shown below the dimension of supply chain management practices by various researchers.

Several researchers have surveyed towards the elements involve in SCM practices but there are only a few of the elements that researcher decided to choose which are:

\subsubsection{Leadership}

Quoted by [17], top-level manager have a better understanding of supply chain management's need because they are the most importance people that can recognise the firm's strategic imperatives to remain competitive in the market place. Besides, as a leader needs to have powerful influenced and respect from organization so that supply chain management practices is easy to implement in the organization [18]. Hence, a leader can improve decision making process, effectively and efficiently to enhance organization performance as well as profitability.

Table 2. Dimension of Supply Chain Practices

\begin{tabular}{|c|c|}
\hline Elements & Source \\
\hline $\begin{array}{c}\text { Strategic supplier partnership, customer relationship, } \\
\text { information sharing, information quality, internal lean } \\
\text { practices, postponement. }\end{array}$ & {$[11]$} \\
\hline $\begin{array}{c}\text { Concentration on core, competencies, Use of } \\
\text { inter-organizational, systems (e.g. EDI), Elimination of } \\
\text { excess inventory levels. }\end{array}$ & {$[12]$} \\
\hline $\begin{array}{c}\text { Supply chain integration, Information sharing, Supply chain } \\
\text { characteristics, Customer service management, Geographical } \\
\text { proximity, JIT capability. }\end{array}$ & {$[13]$} \\
\hline Logistics, Supplier relations, Customer relations, Production. & {$[14]$} \\
\hline $\begin{array}{c}\text { Supplier base reduction, Long-term relationship, } \\
\text { Communication, Cross-functional teams, Supplier } \\
\text { involvement. }\end{array}$ & {$[15]$} \\
\hline $\begin{array}{c}\text { Leadership, Intra-organizational relationships, } \\
\text { Inter-organizational relationships, Logistics, Process } \\
\text { improvement orientation, Information systems, Business } \\
\text { results and outcomes. }\end{array}$ & {$[16]$} \\
\hline
\end{tabular}

\subsubsection{Supplier Relationship}

[19] stated that suppliers play more direct role in an organization's quality performance. Through close bonded relationships, supply chain partners are more willing to share risks and reward and be able to maintain the relationship over a longer period of time [20,21]. Therefore, strategically managed long-term relationship with supplier has positive impact on a firm's supplier performance [22].

\subsubsection{Customer Focus}

Focusing and maintaining the customer relationship will enable the organizations to be more responsive towards customers' needs and will result creating greater customer loyalty, repeat purchase and willing to pay premium prices for high quality product [23]. Besides, the main goals of SCM are customer satisfaction and their loyalty as [24], customer relationship management is an important component of supply chain management practices [25].

\subsubsection{Quality Information and Analysis}

Information quality includes an aspect such as accuracy, timeliness, adequacy and information exchanged credibility [26]. Based on [3], organization needs to review their information as a strategic asset and ensure that the information flows with minimum delay and distortion. In addition, [27] also notes that information shared must be accurate so that the best SCM solution will be obtain. The use of statistical tools and technique will also provides information that help to control management to make an effective decision in managing quality for the organization [28].

\subsubsection{Internal Lean Practice}

Internal lean practices are the activities of eliminating waste such as cost and time in manufacturing system. The 
term lean is refer to a system that use less input to produce at a mass production speed and at the same time be able to offer more variety to the end customers [29-31]. Therefore, lean thinking and lean practices have become very important aspects to achieve SCM effectiveness [3].

\subsection{Organizational Performance}

Organizational performance (OP) refers to how well an organization achieves its market-oriented goals as well as its financial goals. According to [32], performance measurement is common tool in any organization for measuring financial aspect, non-financial aspect, or both financial and non-financial measurement. Each perspective includes a series of performance measures:

Table 3. Organizational Performance Measures

\begin{tabular}{|c|c|c|}
\hline OP measures & Description & Reference \\
\hline Financial & $\begin{array}{c}\text { Financial perspective takes the viewpoint of the company shareholders and } \\
\text { typically uses traditional financial measures such as operating cash flows, return } \\
\text { on investment (ROI) and changes in operating income over time. }\end{array}$ & \\
\hline Customer & $\begin{array}{c}\text { Customer perspective addresses product and form differentiation strategies as well } \\
\text { as value creation from the viewpoint of the organization's client base. It includes } \\
\text { non-financial measures such as market share, consumer satisfaction and product or } \\
\text { service delivery time. }\end{array}$ & [33], [34], [32] \\
\hline $\begin{array}{c}\text { Internal business } \\
\text { process }\end{array}$ & $\begin{array}{c}\text { Includes the efficiency and effectiveness of the firm's operation. This perspective } \\
\text { frequently includes non-financial measures such as product and service quality, } \\
\text { production or performance cycle time and process quality. }\end{array}$ & \\
\hline Innovation and \\
learning growth & $\begin{array}{c}\text { Innovation and learning growth focuses on the creation of organizational value } \\
\text { through employees and innovative practices. The measures would be employee } \\
\text { turnover, employee cross-training and skills level, patents and other indicators that } \\
\text { relate to product development. It also focuses on the employee's capability, } \\
\text { information system quality, and the effects of organizational alignment to achieve } \\
\text { the goal of the organization. }\end{array}$ & \\
\hline Financial & $\begin{array}{c}\text { Financial perspective takes the viewpoint of the company shareholders and } \\
\text { typically uses traditional financial measures such as operating cash flows, return } \\
\text { on investment (ROI) and changes in operating income over time. }\end{array}$ & \\
\hline Customer & $\begin{array}{c}\text { Customer perspective addresses product and form differentiation strategies as well } \\
\text { as value creation from the viewpoint of the organization's client base. It includes } \\
\text { non-financial measures such as market share, consumer satisfaction and product or } \\
\text { service delivery time. }\end{array}$ & \\
\hline
\end{tabular}

\section{A Proposed Research Model}

Based on the literature review, many previous studies were explored about SCMP and OP. This research aimed to analyze the relationship between SCMP and OP for Malaysian automotive industries. Proposed research model of this study as presented in Figure 1 below:

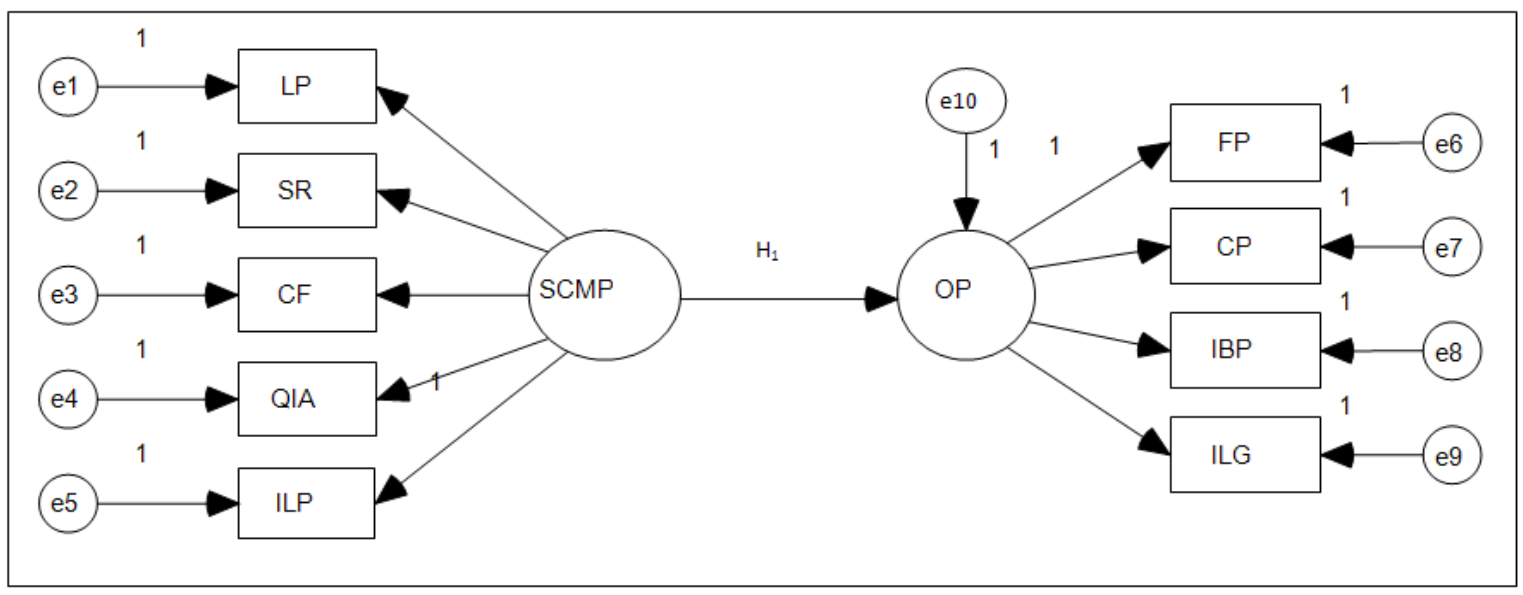

* $\mathrm{LP}=$ leadership, $\mathrm{SR}=$ supplier relationship, $\mathrm{CF}=$ customer focus, $\mathrm{QIA}=$ quality information and analysis, ILP= internal lean practice, $\mathrm{SCMP}=$ supply chain management practices, $\mathrm{OP}=$ organizational performance, $\mathrm{FP}=$ financial, $\mathrm{CP}=$ customer, $\mathrm{IBP}=$ internal business $\mathrm{process}$ and, $\mathrm{ILP}=$ innovation and learning growth.

Figure 1. The Proposed Model of the Study 
The Relationship between Supply Chain Management Practices (SCMP) and Organizational Performance (OP).

According to [4] suggest that efficient SCM may have a significant effect on organizational performance as the performance of an organizational to fulfil various customers' demands or to improve the efficiency of the organization itself can be different depending on the characteristic and utilization focus of supply chain practice.

Moreover, [3] conducted their study for 196 organizations found that SCM practices can lead not only to enhanced competitive advantage but also to improved organizational performance. In addition, based on the study towards Turkish SMEs also found that SCM practices have direct and significant impact on operational performance [11]. Other than that, [35] in their study found that SCM practices are able to give impact on high and low levels of performance in Australian manufacturing companies. [36], state that in order for firm to perform better, to improve performance such as lead time, market share, sales level and others, they should implement SCM practices. Therefore, the following hypothesis is proposed, H1.

\section{Research Methodology and Hypotheses}

In this study, structured questionnaire was use as sampling method. The population of this study are comprised in Malaysian automotive industry. Next, questionnaire will be distribute to the manager in various Malaysian Automotive Industry. The next process is analyzing the data. Two statistical techniques were adopted in order to analyze the data. First, Statistical Package for the Social Sciences (SPSS) $17^{\text {th }}$ version was used to analyze the preliminary data and provide descriptive analyses such as means, standard deviations and frequencies. Second, Structural Equation Modelling (SEM) using AMOS 6.0 will be use to test the measurement model. SEM technique was utilize to perform the require statistical analysis of the data from the survey. Exploratory factor analysis, reliability analysis and confirmatory factor analysis to test for construct validity, reliability and measurements loading were performed. Having analyzed the measurement model, the structural model was then being tested and confirmed.

The supply chain management practice framework developed in this study proposes that SCMP has a direct impact on OP. Therefore, based on the literature review and the research framework, the following hypotheses of the study have been developed:

$\mathrm{H1}$ : There is positive and direct significant relationship between SCMP and OP in Malaysian automotive industry.

\section{Conclusion}

Supply chain management practices and organizational performance measure are become most importance strategy and it involves local car manufacturer and automotives suppliers. Therefore, it will be an effort for them to become more effective and competitive by enhancing the organization's ability to improve quality, business operation, customers and employee satisfaction, and business performance. In addition, the finding and the proposed conceptual model of this research can be used and contribute not only to the academic but also to the industry especially to the suppliers development and Malaysian automotive industry practitioners.

\section{Acknowledgements}

The authors would like to acknowledge the Ministry of Higher Education (MOHE) for the financial funding of this research thought Research Acculturation Grant Scheme (RAGS) and Research Management Centre (RMC). UPSI for Research University Grant (RUG). Furthermore, the authors would like to thank the anonymous reviewers for their valuable suggestion for the improvement of this article.

\section{REFERENCES}

[1] M. C. Cooper, D. M. Lambert, and J. D. Pagh, "Supply chain management: more than new name for logistics," International Journal of Logistics Management vol. 8 no. 1, pp. 1-14, 1997.

[2] M. L. Fisher, "What is the right supply chain for your product?," Harvard Business Review, vol. 75, no. 2, pp. 105-116, 1997.

[3] S. Li, S.S. Rao, T. S. Ragu-Nathan, and B. Ragu-Nathan, "Development and validation of a measurement instrument for studying supply chain management practices," Journal of Operations Management, vol. 23, no. 6, pp. 618-641, 2005.

[4] R. Narasimhan, and J. R. Carter, "Linking business unit and material sourcing strategies, " Journal of Business Logistics, vol. 19, no. 2, pp. 155-71, 1998.

[5] S. W. Kim, "Effects of supply chain management practices, integration and competition capability on performance,"

[6] Supply Chain Management: An International Journal, vol. 26, no.10, pp. 1084-1107, 2006.

[7] F. Viloso, and R. Kumar, "The automotive supply chain: Global Trend and Asian Perspective," ERD Working Paper Series No. 3, Department of Engineering and Public Policy. Paper 134, 2002.

[8] W. M. J. Hugo, J. A. Badenhorst-Weiss, and E. H. B. Biljon, Supply chain Management: Logistics in perspective, 1st edition. Pretoria, 2004.

[9] M. Christopher, Logistics and Supply Chain Management-Creating Value-Adding Networks, Financial Times, Prentice Hall, 2005.

[10] C. Gansler, R. E. Luby Jr., and B. Kornberg, Supply Chain 
Management in Government and Business, in Transforming Government in Gansler J, and Luby, JR, The IBM Centre for the Business for Government Series, 2004.

[11] M. R. Leenders,, and H. E. Fearon, Purchasing and supply chain management (11th ed.). Chicago: Irwin, 1997.

[12] S. Koh, M. Demirbag, E. Bayraktar, E. Tatoglu, and S. Zaim, "The impact of supply chain management practices on performance of SMEs," Industrial Management \& Data Systems, vol. 107, no. 1, pp. 103, 2007.

[13] U. Y. Alvarado, and H. Kotzab, "Supply chain management: the integration of logistics in marketing," Industrial Marketing Management, vol. 30, no.2, pp. 183-198, 2001

[14] K. C. Tan, S. B. Lyman, and J. D. Wisner, "Supply chain management: a strategic perspective," International Journal Operation \& Production Management, vol. 22, pp. 614-31, 2002.

[15] G. Ulusoy, "An assessment of supply chain and innovation management practices in the manufacturing industries in Turkey," International Journal of Production Economics, vol. 86, pp. 251-70, 2003.

[16] I. J. Chen., and A. Paulraj, "Towards a theory of supply chain management: the constructs and measurement," Journal of Operation Management, vol. 2, no. 2, pp. 119-150, 2004.

[17] K. Burgess, P. J. Singh, and R. Koroglu, "Supply chain management: a structured literature review and implication for future research," International Journal of Operation \& Production Management, vol. 26, no. 7, pp. 703-723, 2006.

[18] C. K. Hahn, C. A. Watts, and K. Y. Kim, "The supplier development program: a conceptual model," International Journal of Purchasing and Material Management, vol. 26, no. 2, pp. 2-7, 1990.

[19] E. Sadikoglu, and C. Zehir, "Investigating the effects of innovation and employee performance on the relationship between total quality management practices and firms performance: An empirical study of Turkish firms," International Journal of Production Economics, vol. 127, pp. 13-26, 2010.

[20] D. M. Lascelles, and B. G. Dale, "The buyer-supplier relationship in total quality management," Journal of Purchasing and Material Management, vol. 25, no. 3, pp. 10-19, 1989.

[21] Landeros, R., and Monczka, R. M., Cooperative buyer/seller relationship and a firm's competitive posture, Journal of Purchasing and Material Management, 1989, 9-18.

[22] M. C. Cooper, and L. M. Ellram, "Characteristic of supply chain management and the implications for purchasing and logistics strategy," International Journal of Logistics Management, vol. 4, no. 2, pp. 13-24, 1993.

[23] A. S. Carr, and J. N. Pearson, "Strategically managed buyer-seller relationship and performance outcomes," Journal of Operation Management, vol. 17, no. 5, pp.
497-519, 1999.

[24] G. Stalk, and T. M. Hout, Competing against time. The free press, New York, 1990.

[25] D. Noble, Purchasing and supplier management as a future competitive advantage edge, Logistic Focus, vol. 5, no. 5, pp. 23-27, 1997.

[26] K. C. Tan, V. R. Kannan, and R. B. Handfield, "Supply chain management: supplier performance and firm performance," International Journal of Purchasing and Materials Management, vol. 34, no. 3, pp. 2-9, 1998.

[27] R.M. Monczka, K. J. Petersen, R. B. Handfield, and G. L. Ragatz, "Success factors in strategic supplier alliances: the buying company perspective," Decision Science, vol. 29, no. 3, pp. 5553-5577, 1998.

[28] D. Alvarez, "Solving the puzzle of industry's rubic cubeeffective supply chain management," Logistic Focus, vol.2, no. 4, pp. 2-4, 1994

[29] N. Zakuan, S. M. Yusof, and A. M. Shaharon, The link between total quality management and organizational performance in Malaysian Automotive Industry: The mediating role of ISO/TS16949 efforts. Proceeding of the IEEE IEEM, Hong Kong, pp. 439-443, 2009.

[30] J. Womack, and D. Jones, Lean Thinking. Simon and Schuster, New York, 1996.

[31] R. McIvor, "Lean supply: the design and cost reduction dimensions," European Journal of Purchasing and Supply Chain Management, vol. 7, no. 4, pp. 227-242, 2001.

[32] D. H. Taylor, "Supply chain improvement: the lean approach," Logistic Focus vol. 7, pp. 14-20, 1999.

[33] N. F. Habidin, S. M. Yusof, B. Omar, S. I. S. Mohamad, and S. E. Janudin, "A proposed strategic balance scorecard model: strategic control and organizational performance in Malaysian automotive industry," Journal of Business and Management, vol. 1, no. 6, pp. 39-40, 2012.

[34] J. B. Butler, S. C. Henderson, and C. Raibon, "Sustainability and the balance scorecard: integrating green measures into business reporting," Management Accounting Quarterly Winner, vol. 12, no. 2, pp. 1-10, 2011.

[35] R. McPhail, C. Herrington, and C. Guilding, "Human resources managers' perception of the application and merit of the balance scorecard in hotels," International Journal of Hospitality Management, vol. 27, pp. 623-631, 2008.

[36] Petrovic-Lazarevic, Sohal, Baihaiqi, Supply chain management performance the Australian manufacturing industry, 2007. Online Available: http://www.buseco.monash.edu.au/mgt

[37] Y. L. Alain, T. S. Felix, K. B. Ooi, and J. J. Sim, "Can Malaysian firms improve organization/innovation via SCM?," Industrial Management \& Data System, vol. 111, no. 3, pp. 410-431, 2011. 